DOI :

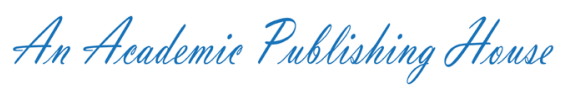

\title{
Diaspora in the Land of Sad Oranges
}

\author{
Yousef Alhomouz
}

Istanbul Aydin University, Department of English language and literature

\begin{abstract}
This paper deals with the notion of Diaspora regarding the short story of the land of Sad Oranges by Ghassan Kanafani. The orange in this work represents and remains metaphorical; a faded memory instead of a symbol of the happy existence the family lived before its children becoming exiles. The orange represents a psychological, familial, and social catastrophe in the tale. It represents the political asylum, pessimism, and acceptance of the reality of loss. The sorrowful country portrays the several multiple aspects of the Palestinian catastrophe in many shapes and it is a collection of several bends against sensation and memories, as well as a group of many bends at the front of the human agony contained in this mirror. Kanafani latest attempt to construct his rise to the concept of the Palestinian perspective, which he wants to depict with words, is The Land of the Sad Oranges. Kanafani here explains the sorrow and the bitterness of being an expatriate and expelled from the motherland by force.
\end{abstract}

KEYWORDS: Exile, Diaspora, Homesickness, Orange, Expatriation.

\section{INTRODUCTION}

During the last ten years, the notion of Diaspora and locality had acquired compound modern meanings in the discourse of policy and in cultural and social studies as well. The concept of Diaspora, particularly has gained many different notions and ideas that are connected to concepts like universal severance, national immigration and hybridity of cultures (Diaspora, identity and religion, 2016). Thinking about diaspora and nationalism is nearly like thinking about the distance and homesickness. The word "diaspora" itself cannot be dismissed as insignificant. The evolution of its uses, on the other hand, is critical for those seeking to comprehend developments in nationalism problems since the 1960s. The word "Diaspora" is an ancient Greek term, which used for the first time in the Hebrew Bible to emphasize the eternal and divine punishment that Jews would face if they would not respect and obey the rules of God. Before the 1960s, this old term was mostly used in religious contexts. With the sense of "ethnic minority," it was most commonly applied to Jews, but also to Catholics and Protestants. Furthermore, since it originated from the Jewish past, it held the stigma of exile and oppression: "diaspora" represented expulsion and ostracism. New innovations have arisen since the 1960s, and the term has taken a far more positive connotation while also keeping the negative connotation. It has undergone radical secularization, with more and more nonreligious uses becoming permissible in the social sciences, as opposed to its older uses marked by religious (Jewish, Catholic, and Protestant) tradition. This transition was helped by a second intellectual element. However, academic studies started to explore the problem of the "existence" or "supporting" of African peoples in the New World, allowing communities who were frequently discriminated against because of the skin colour to see themselves as having a heritage and to create connections with Africa. The evolution of the connection between the state of Israel and world Jewish people was another factor in the formation of a more optimistic view of "diaspora." However, the declaration of the Jewish state stemmed from the Zionist rejection of a scattered Jewish life among all the communities. Nonetheless, in the matter of fact, millions of Jews failed to move to Israel under the Law of Returning, citing a "real connection" to the country's destiny, lent credence to the notion that a nation's borders were not simply its geographical boundaries. The term "diaspora" has taken on a positive meaning. The probability about an ethnic and religious relation between a geographical core and scattered populations, coupled with increasing theoretical and academic awareness of possible multiple racial or national categories, results in a separation in the concept as “diaspora." Since 1948, it possibly means a scattering nation of people without a motherland (The Palestinian diaspora). On the other hand, a diversely cultural society that believes in a collective heritage but it has no connection to a core at all (The African or the Black diaspora). 
In recent decades, the definition of the word "diaspora" has shifted away from long-established Diasporas like the Jewish, Armenian, or Greek encounters or towards a slew of fresh and contentious reference points. Religion seems to have slipped into the past with this expansion of context into the broader field of migration and transnationalism. Finally, the comparative potential of various research traditions, as well as the breadth of ethnographic field research offered at the meeting, led us to rethink our viewpoint. While we do not intend to restrict the concept of 'diaspora' to religious enclaves within distinct denominational territories, here it isexplicitly highlight the importance of religious belief, symbolic references and hierarchical systems in the creation of diasporic identities. (Diasporic aspects of religion. P.6).In 1947, the population of Palestine of Arabs exceeded nearly one and a half million, they were living in the countryside. Many years later, the population was almost five millions citizens in which they used to live outside the land of mandatory Palestine, which is, in the Diaspora and the occupied land of the West Bank and Gaza. Currently, Jordan has the largest Palestinian community and individuals, with Palestinians founding more than half of the population. Other huge external population is found in Lebanon, Kuwait, Syria, and Saudi Arabia, with a tiny small part in Iraq, Libya and Egypt. Even Cyprus but it is small population. United States of Americahas Christians originally from the cities of the West Bank. During the mandate era of Britain, many Palestinians who used to work for the Palestinian government migrated to Britain, in which many others, mostly included hundreds of students between 1960s and 1970s, also followed them. In South America, refugees who hadescaped from the Turkish compulsory military service in the world I founded Chile, Argentina, the Palestinian gatherings and community. Their population increased right after 1948, and the societies in South America, which are one of the richest in the Palestinian Diaspora, have four generations. However, some wealthy Palestinians were enjoying family relations as well as business relations in different countries of the Arab nations; they already were leaving Palestine within a short time after the declaration of the country's division and partition by the UN, which was stated in 1947. Amid the 1948 conflict, the overwhelming majority of Palestinian refugees fled through violent engagements between the covert Israeli forces (Haganah) and the Palestinian revolt. However, amid the hostilities between Egypt's, Syria's, and Iraq's troops, the majority of them initially sought refuge and shelter in neighboring Arab nations or other parts of Palestine, particularly during the heavy bombardment and countering in every region of Palestine. Furthermore, the massacre of 254 people in the village of Dayr Yasin. Furthermore, many other people had fled to various sections of the West Bank and Jordan just after the arrival of the Arabian troops, seeking refuge in territories within Jordan's authority and administration. The others in the coastal regions, on the other hand, fled to Gaza or Egypt itself in search of protection.

\section{DIASPORA IN THE LAND OF SAD ORANGES}

The story of five pages, which talks about the Palestinian Diaspora written by Ghassan Kanafani, is a first person narrator, narrated by a young child to a friend. Fundamentally, it is a short story, which talks about the lack, absence, loss and deprivation of childhood. In addition, the story also is a heartbreaking tale about two families who were exiled from their homes. The story is considered as Kanafani's autobiographical story ever, the protagonist's sense of instability, dislocation, terror and uncertainty is reflected in Kanafani's illustration, which is based on the author's childhood expulsion and deprivation from Palestine. Since the time in which there were big vans waiting at Kanafani's door, also "with rapid nervous motions, several blankets had been tossed down into it from here and there. Until the ending of the case, while and after the retreatment of the Arabian armies from Palestine, Kanafani escaped terrified in the evening, saying, "As I was fleeing and running away from home, I also escaped from my childhood as well." Moreover, Kanafani recreates not just the consequences of real events, but also the surrounding moods and feelings. In the matter of fact, this depiction of scenes from the writer's own personal life results in a real catastrophe, which is not diminished by our understanding of how closely it reflects and resembles our reality. Focusing on daily life of tragedy of the Palestinian family, Kanafani averts higher hypothesizing of the historic cases. However, the story as we know has its own foundation in individual and personal testament. Through rejecting to permit his own ideas and thoughts of the reasons of the escape of his family from Palestine, Kanafani raises this tale from the risks of his autobiographical, political alienation and endows his characters a comprehensive charisma, enhancing this feature by their expulsion and exile icon. Thus, the story can be read from different angles as memories or as a clear and distinctive depiction of Palestine condition and as a performance of all who agonize the excruciating sense of Diaspora. Hence the tale ascents from personal story and historical to a symbolic one.

As the family moves from Jaffa to Acre, the plot starts on a deceivingly positive note. "Our exit was not catastrophicin any way. We were just like everyone else who spends the festival season in a different city every year ". The plot continues with an almost queer tone as the young man describes how he enjoys his days in Acre because they save him from attending school. At that, time there is the massive assault on Acre, which totally shifts the scene. Kanafani compares the optimistic mood of the beginning of the narrative with the sad tone of the ending. Families and their properties are crammed together into the truck as it drives through orange 
groves, witnessing gunshots inside the region. They come to a halt and buy some oranges, which the kid connects with the sound of sobbing. Because of the child narrator's connection with crying, oranges became an important symbol to him: "I felt then that the oranges were something dear, and these tall, clean fruits were cherished things in our eyes" (p. 58). Hence, what the little kid realizes soon becomes very true for Palestine that had been abandoned is called "The Land of sad Oranges", (P.58).Also, when they move far away, Kanafani links Palestine and sorrow by the father words:"And all the orange trees which your father had abandoned to the Jews shone in his eyes, all the well-tended orange tree which he had bought one by one were printed on his face and reflected in the tears which he could not control in front of the officer at the police post." (P.58).

So here, the father expressing his deep sorrows and sadness as they enter Lebanon and leave behind the orange trees as all are weeping now. Moreover, the narrator is infected by adult's anguish.

"The colored pictures which were handed out to us in the school chapel showing the Lord having. compassion on children and smiling in their faces seemed like another of the lies made up by people who open strict schools in order to get higher fees". (p. 58)

For a young boy, these are cuttingly naive thoughts; he is only guided to it by terrible situations. We can see the origins of the boy's lack of innocence in this quasi-meditative passage, which contrasts sharply with his earlier jubilation at skipping school. The family has no place to stay the night; however, the uncle does some help. Hence, he heads to a Jewish home, he opens the door, and the Jewish says to them to "go to Palestine". (P.59). His hopelessness scares everyone, while the Jews come together in another place or room. The Palestinian family finally gathers on the ground after three days and nights. The family then goes to Sidon in Lebanon, and at May 15 in 1948, the Arab armies arrive Palestine. Everyone now has a hope of triumph for it will help all refuges to go back to their homes in Palestine. Out of happiness, the families even ran after the forces and threw cigarettes at them. However, their hopes and wishes are gone in vain. "We were duped, and we were tricked by the reality with all its soreness and bitterness. Despair and low spirits have found their ways back to people faces" (P.60). In addition to this hardship, the father becomes extremely agitated and irritable, he asks the young kids to climb the peak each day, and the reason for that is just to prevent the children from asking for the breakfast.

Someday, the father out of a sudden leaps and pounces on the car boot and he started to throw its loads. The father here is trembling and shaking "like he has received an electric shock" (P.61), also his eyes are shining, his wife recognizes what he was looking and searching for and she directs the children again to the mountain. Subsequently, the narrator by accident has heard the father saying that he is planning to kill them all including himself. The father is extremely hopeless in a way that makes him feels that death is the only liberation and solution. While getting close of his death, the teller comes up from purity into real experience. "When I abandoned home, I abandoned my babyhood too... Things had reached and were out breaking the climax in which the only solution left for us was just one bullet in the head of every one of us.When the narrator returns and peeks into the room, the father has become ill and is in bed. When he looks at the father's enraged expression, he notices two things on the table: the weapon and the orange he purchased a fair while ago. "The orange was shriveled and started to dry up"

The orange fruit represents a happy and a comfortable life. Oranges are fruits of hard work; this life has been a work of passion and love. Circular, complete, perfect and ideal, all of them feed the people and it is tasty as well. When the refuges were forced to leave Palestine, they were also forced to leave behind them the world of oranges. In addition, the sere and shriveled orange fruit here is important; representing the loss of a joyful and comfortable life that now, they are deprived and expelled from, also their shortness of food and their starvation every day. Hence, it is also reminds us of the burnt seeds at the conclusion of "That day he was a child". In the final story, those burnt seeds are representing the massive devastation of the aspirations of Palestine by a foe who are willing to commit a carnage and slaughter even little children. The dehydrated and withered orange symbolizes the status of the Palestinian expectations and hopes at this specific moment in history.

Rifles are also eminent factor in this tale, guns here are appearing many times and representing the termination or doom and death of their previous content. The plan of killing everybody that the father has made, shows his capitulation and despair even irritation as well at being obliged into a circumstance he sees as desperate, without any available resolution but doom. Kanafani's decision of narrating this tale from a child's point of view is essential and extremely functional in creating the story a chilling tale instead of political issues, in which it may become from an adult's point of view that might be involved. To make matters worse, the feeling of dislocation and panic is furthered by the dissimilarity between the guiltlessness of the child and his lack of knowledge and gloomy incidents telling the life of his family along with the bigger lives of the Palestinians and nationals. The sarcastic dimension between what the reader knows and what the little boy knows is excessively efficient and effective style to make out the horrifying feelings of this tale. 
"Your father was still there trembling with temperature that evening, long after the darkness had spread over the house. Your mother sat beside him. Our eyes glistened like cats' eyes in the dark. Our lips were sealed as if they were never opened, as if they were remnants of an old injury. We were heaped up there, withdrawn from our childhood, away from the land of oranges...oranges that died, an old farmer once told us, if watered by strange hands. Your father was still sick, thrown down on his bed, and your mother was gnawing tragic tears that never left her eyes. I snuck into the room, an outcast. I saw your father's face quiver with broken rage, and I saw, at the same time, that black pistol on the low table. Near it was orange. The orange was wrinkled and dry".

Kanafani speaks about the grief that he had faced during the diaspora; he emphasizes the excruciating pain that the family feels in exile. In addition, the orange here symbolizes happiness, comfortable life, tolerance and serenity in Palestine. The small piece of orange also symbolizes freedom and simple life, saying that intruders should not touch it; otherwise, it will not keep its good qualities. Moreover, the death of the orange is used as a metaphoric expression that shows the death of innocence of their childhood, the Source of livelihood as well. By the death of the orange and got wrinkled, the dreams of the children in the story have subsided and turned in vain.

\section{REFERENCES}

1. Attar, S. (January 01, 2007). BURIED IN THE DEEPEST RECESSES OF MEMORY: A QUEEN OR A SLAVE? THE VISION OF GHASSAN KANAFANI AND EMILE HABIBI OF THE CITY OF HAIFA. Arab Studies Quarterly, 29, 2, $37-$ 56.

2. Bamia, A. (April 01, 1989). The Image of the Jew in Arabic Literature: The Case of Some Palestinian Writers. Shofar, 7, 3, 32-42.

3. In Alfonso, C., In Kokot, W., \& In Tololyan, K. (2016). Diaspora, identity and religion: New directions in theory and research.

4. Khoury, E. (August 01, 2013). Remembering Ghassan Kanafani, or How a Nation Was Born of Story Telling. Journal of Palestine Studies, 42, 3, 85-91.

5. Sacdi, A. H. (November 06, 2015). Representations of Exile and Return in Palestinian Literature. Journal of Arabic Literature, 46, 216-243.

6. Salam, M. (April 01, 2013). Palestinian Literature: Occupation and Exile. Arab Studies Quarterly, 35, 2, 110 129.

7. Smith, P. A. (January 01, 1986). The Palestinian diaspora, 1948-1985. Journal of Palestine Studies. , 153, 91-108.

Citation: Yousef Alhomouz, "Diaspora in the Land of Sad Oranges", American Research Journal of English and Literature, Vol 7, no. 1, 2021, pp. 1-4.

Copyright (C) 2021 Yousef Alhomouz, This is an open access article distributed under the Creative Commons Attribution License, which permits unrestricted use, distribution, and reproduction in any medium, provided the original work is properly cited. 